\title{
PEMBUATAN DAN OPTIMASI SENSOR WARNA LOGAM BESI TERLARUT DALAM AIR DENGAN MATRIKS KARAGENAN
}

\section{Fabrication dan optimization color sensor of iron in water with carrageenan matrix}

\author{
Nindita Clourisa Amaris Susanto ${ }^{1 *}$, Mudasir $^{2}$, Dwi Siswanta ${ }^{2}$ \\ ${ }^{1}$ Program Studi Kimia, Fakultas Sains dan Teknologi, Universitas Jambi, Jl. Lintas Jambi-Muara Bulian Km. 15, \\ Mendalo Darat, Jambi Luar Kota, Jambi 36122 \\ ${ }^{2}$ Departemen Kimia, Fakultas Matematika dan Ilmu Pengetahuan Alam, Universitas Gadjah Mada, Sekip Utasa BLS 21 \\ Depok, Sleman, Yogyakarta 55281 \\ *Email : ninditaclourisa@unja.ac.id
}

Received : 21 Juni 2020; Accepted : 14 Juli 2020; Publish : Juli 2020

\begin{abstract}
Abstrak
Karagenan merupakan polimer alam anionik yang mempunyai sifat hidrogel. Kemampuan tersebut memberikan kemungkinan karagenan dijadikan matriks untuk sensor logam besi di dalam air. Sensor logam besi diukur sebagai ion $\mathrm{Fe}^{2+}$. Ion $\mathrm{Fe}^{2+}$ mempunyai kemampuan membentuk kompleks stabil dengan 1,10fenantrolin dan memberikan warna jingga. Dalam Pengembangan sensor warna didasarkan pada imobilisasi gugus kromofor pada material pendukung. Oleh karena itu pada penelitian dilakukan pembuatan sensor warna dengan gugus kromofor kompleks $\mathrm{Fe}^{2+}$ dengan 1,10-fenantrolin di dalam mtriks karagenan. Matriks dibuat dalam bentuk beads kemudian dilakukan optimasi untuk panjang gelombang, 1,10-fenantrolin yang diimobilisasi, $\mathrm{pH}$ dan waktu kestabilan perubahan warna. Hasil penelitian diperoleh modifikasi matriks dalam bentuk beads campuran karagenan kappa dan iota sehingga menghasilkan sensor warna tanpa pelindian. Hasil sensor warna divisualisasi dengan mata dan spektrofotometer UV-Vis. Perubahan warna sensor warna dari putih gading menjadi jingga kemerahan. Kondisi optimum yang diperoleh dari penelitian meliputi panjang gelombang maksimum $510 \mathrm{~nm}$, konsentrasi 1,10-fenantrolin yang diimobilisasi $3000 \mathrm{mg}$ $\mathrm{L}^{-1}$ volume total larutan pembuat beads, $\mathrm{pH}$ larutan besi adalah 2, dan waktu kompleksasi 15 menit.

Kata kunci : sensor warna, karagenan, besi, optimasi, matriks
\end{abstract}

\begin{abstract}
Carrageenan is an anionic natural polymer which has hydrogel properties. This capability provides the possibility of carrageenan as matrix for sensors of metal in water. Iron metal sensor are measured as $\mathrm{Fe}^{2+}$. It is making stable complex to 1,10-phenantroline and the color is orange. The development of color sensor is based on the immobilization of chromophore groups in supporting material. The research obtained modification of matrix by mixture kappa and iota carrageenan beads to produce color sensor without leaching. Beads carrageenan optimized for wavelength, concentration of 1,10-phenantroline, $\mathrm{pH}$ and stability time of color change. The color sensor visualized by naked-eyes and UV-Vis spectrophotometer. Color change of sensor showed ivory to orange red. The optimum conditions obtained a maximum wavelength of $510 \mathrm{~nm}$, phenanthroline concentration, the $\mathrm{pH}$ of iron solution was 2 , and a complexation stable sensor was 15 minutes.
\end{abstract}

Keyword : color sensor, carrageenan, iron, optimation, matrix

\section{PENDAHULUAN}

Besi dalam air terlarut sebagai $\mathrm{Fe}^{2+}$ (ferro) dan $\mathrm{Fe}^{3+}$ (ferri). Konsentrasi besi terlarut dalam air yang diperbolehkan tidak boleh lebih dari 1,0 $\mathrm{mg} \mathrm{L}^{-1}$. Jika melebihi batas tersebut dapat menyebabkan gangguan fisik pada air seperti warna, bau dan rasa. Dalam bidang kesehatan, zat besi dalam dosis besar pada manusia bersifat toksik karena kosumsi berlebih dapat menyebabkan peningkatan 
feritrin dan hemosiderin yang menyebabkan hemokromatosis.

Beberapa metode yang telah digunakan untuk menentukan logam antara lain spektroskopi serapan atom (SSA) [16], inductively coupled plasma-optical emission spectrometry (ICP-OES) [3], inductively coupled plasma-mass spectrometry (ICP-MS) [8]. Identifikasi dan analisis kuantitatif ion logam menggunakan metode-metode tersebut memerlukan instrumen mahal dan tenaga terlatih untuk melakukan analisis sampel. Terdapat beberapa metode yang relatif lebih murah seperti voltametri [6], potensiometri [18]. sMetode tersebut digunakan untuk deteksi logam dan kuantifikasi, tetapi membutuhkan waktu yang lebih panjang ketika memerlukan pengujian sampel dalam jumlah banyak dan umumnya tidak bisa diterapkan secara langsung di lokasi. Oleh karena itu, diperlukan metode identifikasi semikuantitatif atau kualitatif yang lebih sederhana melalui sensor.

Sensor untuk logam dapat memberikan prosedur yang murah, sederhana, cepat dan mudah dalam pemantauan harian secara rutin [5]. Visualisasi hasil sensor warna yang didasarkan pada perubahan warna yang terjadi menggunakan mata atau spektrofotometer UVVis [15]. Beberapa laporan mengenai sensor warna logam antara lain Deteksi kolorimetri $\mathrm{Fe}^{2+}$ dengan mengimobilisasi agen pengompleks 2-(2'-piridil) imidazol (PIMH) dalam serat nano polivinilbenzil klorida (PVBC) [11]. Sensor logam menggunakan nanofiber [17]. Proses fabrikasi serat nano rumit dan relatif mahal. Sensor warna ion merkuri di dalam air menggunakan membran sebagai pengikat dithizon melalui gugus kromofornya [2]. Sensor warna $\mathrm{Cu}$ (II) dan $\mathrm{Fe}(\mathrm{III})$ menggunakan membran hidrogel poli asam aspartat [19].

Berdasarkan penelitian tersebut menunjukkan bahwa material pendukung yang digunakan yaitu polimer sintetik dan membutuhkan agen pengompleks yang spesifik untuk masing - masing logam. Polimer sintetik membutuhkan proses sintesis yang rumit, menghasilkan limbah sisa sintesis dan mahal serta dapat menyebabkan pencemaran lingkungan jika membran habis pakai tidak dibuang secara tepat karena tidak dapat terurai secara hayati. Karagenan merupakan polisakarida alami dari rumput laut yang mempunyai sifat dapat membentuk hidrogel, murah, dapat terurai secara hayati dan tidak toksik [12]. Karagenan merupakan polisakarida anionik ester sulfat yang larut di dalam air dan diperoleh dari ekstraksi alga merah. Karagenan komersial terdapat dalam 3 jenis utama yaitu jenis kappa, iota, dan lambdakaragenan. Reaktivitas kimia karagenan ditunjukkan dengan adanya gugus ester sulfat yang sangat anionik disetiap unit disakarida karagenan dan berkontribusi memberikan sifat hidrofilik [10].

Sifat optik dari ion logam dapat dengan mudah diamati dengan pembentukan kompleks [11]. Kompleks yang terbentuk antara ion logam dengan agen pengompleknya dapat memberikan warna yang spesifik. Besi dalam bentuk ion $\mathrm{Fe}^{2+}$ mempunyai afinitas terhadap ligan yang mengandung amina seperti 1,10 fenantrolin sedangkan $\mathrm{Fe}^{3+}$ tidak [13]. Kompleks kation antara $\mathrm{Fe}^{2+}$ dengan 1,10fenantrolin memberikan warna merah jingga dan stabilitas kompleks tinggi [7]. Pengembangan sensor warna didasarkan pada imobilisasi gugus kromofor pada material pendukung [4]. Oleh karena itu pada penelitian ini dilakukan pemanfaatan gugus anionik ester sulfat sebagai matriks atau material pendukung agar dapat mengimobilisasi kompleks kationik sehingga sensor warna tidak mengalami pelindian dan optimasi kondisi sensor.

\section{METODE}

Bahan-bahan yang dipergunakan dalam penelitian ini adalah bahan-bahan kimia 
dengan kualitas pro analisis (p.a) produksi Merck meliputi $\mathrm{C}_{12} \mathrm{H}_{8} \mathrm{~N}_{2} \cdot \mathrm{H}_{2} \mathrm{O}(1,10$-fenantrolin monohidrat), $\left(\mathrm{NH}_{4}\right)_{2} \mathrm{Fe}\left(\mathrm{SO}_{4}\right)_{2} \cdot 6 \mathrm{H}_{2} \mathrm{O}$ (ferro amonium sulfat heksahidrat), akuabides (Laboratorium Pusat Pangan dan Gizi (PAU) Universitas Gadjah Mada), iota karagenan, кappa karagenan dan lambda karagenan (IPB).

Penelitian ini dimulai dengan persiapan karagenan yang terdiri dari jenis kappa, iota dan lambda karagenan sebagai matriks untuk imobilisasi, karagenan dibuat dalam bentuk beads untuk mendapatkan sensor tanpa pelindian, beads karagenan dikarakterisasi dengan spektrofotometer inframerah. Penentuan kondisi optimum yang mempengaruhi sensor warna logam Fe yang dideteksi sebagai $\mathrm{Fe}^{2+}$. Data hasil optimasi diperoleh melalui spektrofotomrtr UV-Vis dan secara visual. Kondisi optimum meliputi penentuan panjang gelombang, konsentrasi optimal agen terimobilisasi (1,10-fenantrolin), $\mathrm{pH}$, waktu kestabilan sensor.

\section{Pembuatan Bentuk Matrik Karagenan}

Karagenan jenis kappa dan iota dilarukan ke dalam $100 \mathrm{~mL}$ akuabides pada suhu $\pm 80^{\circ} \mathrm{C}$ dan diaduk selama 2 jam. Larutan karagenan dimasukkan ke dalam semprit untuk membentuk beads yang diteteskan ke dalam larutan pencetak yaitu campuran larutan $\mathrm{KCl}$ dan larutan $\mathrm{CaCl}_{2}$ dengan perbandingan 2:1.

\section{Karakterisasi Beads Karagenan}

Beads dikarakterisasi dengan spektrofotometer inframerah pada bilangan gelombang 4000-500 cm-1. Beads dikeringkan di udara tebuka sebelum dikarakterisasi. Karakterisasi dilakukan pada beads sebelum dan setelah proses sensor warna.

\section{Penetuan Panjang Gelombang Maksimum}

Larutan $\mathrm{Fe}^{2+}$ disiapkan dengan konsentrasi 3, 5 dan $10 \mathrm{mg} \mathrm{L}^{-1}$ kemudian 10 beads dimasukkan ke dalam masing-masing konsentrasi larutan $\mathrm{Fe}^{2+}$ hingga beads mengalami perubahan perubahan warna. Kemudian beads dipisahkan dari larutan $\mathrm{Fe}^{2+}$ dan absorbansi beads diukur pada panjang gelombang antara 450-550 nm menggunakan spektrofotometer UV-Vis.

\section{Optimasi Konsentrasi Agen Terimobilisasi 1,10-fenantrolin}

Fenantolin diimobilisasi dalam matriks karagenan dengan variasi konsentrasi 1,10fenantrolin yaitu 1000, 2000, 3000, 4000 dan $5000 \mathrm{mg} \mathrm{L}^{-1}$ dalam volume total larutan untuk pembuatan beads. Larutan $\mathrm{Fe}^{2+}$ disiapkan pada konsentrasi 2, 5 dan $10 \mathrm{mg} \mathrm{L}^{-1}$. Sepuluh beads dari masing-masing variasi konsentrasi 1,10fenantrolin dimasukkan ke dalam larutan $\mathrm{Fe}^{2+}$ hingga beads berubah warna. Beads dipisahkan dari larutan $\mathrm{Fe}^{2+}$ dan divisualisasi dengan mata yang ditunjukkan dengan gambar. Beads diukur absorbansi dengan menggunakan spektrofotometer UV-Vis pada panjang gelombang maksimum.

\section{Optimasi pH}

Larutan $\mathrm{Fe}^{2+} 5 \mathrm{mg} \mathrm{\textrm {L } ^ { - 1 }}$ disiapkan dan dibuat dengan variasi $\mathrm{pH} 2$ hingga 6 dengan menggunakan $\mathrm{pH}$ buffer. Sepuluh beads dengan konsentrasi 1,10-fenantrolin optimum dimasukkan ke dalam larutan $\mathrm{Fe}^{2+} 5 \mathrm{mg} \mathrm{L}^{-1}$ dengan variasi $\mathrm{pH} 2$ sampai 6 hingga beads berubah warna. Selanjutnya beads dipisahkan dari larutan $\mathrm{Fe}^{2+}$ dan divisualisasi dengan mata yang ditunjukkan dengan gambar. Beads diukur absorbansi dengan menggunakan spektrofotometer UV-Vis pada panjang gelombang maksimum.

\section{Optimasi Waktu Kestabilan Sensor}

Penentuan waktu optimal kestabilan sensor dilakukan dengan mempersiapkan larutan $\mathrm{Fe}^{2+}$ 5 dan $10 \mathrm{mg} \mathrm{L}^{-1}$ pada $\mathrm{pH}$ optimum. Satu bead 
dimasukkan ke dalam kuvet yang berisi larutan $\mathrm{Fe}^{2+}$. Beads diukur waktu optimal deteksi kolorimetri dengan spektrofotometer UV-Vis selama 30 menit dengan selang waktu 3 menit.

(a)

(b)

(c)

Gambar 1 Beads (a) kappa karagenan; (b) iota karagenan; (c) kappa dan iota karagenan pada imobilisasi 1,10-fenantrolin 3000 mg $\mathrm{L}^{-1}$ volume total larutan pembuat beads dan konsentrasi larutan $\mathrm{Fe}^{2+} 10 \mathrm{mg}$ $\mathrm{L}^{-1}$

\section{HASIL DAN PEMBAHASAN Sensor Warna Logam Besi dengan Matriks Karagenan}

Pembuatan sensor warna logam $\mathrm{Fe}$ dengan mengimobilisasi gugus kromofor ke dalam matriks. Ion $\mathrm{Fe}^{2+}$ dapat membentuk kompleks berwarna merah jingga dengan 1,10fenantrolin. Oleh karena itu deteksi yang didasarkan pada warna untuk Fe diukur sebagai $\mathrm{Fe}^{2+}$ yang dapat menunjukkan perubahan warna di dalam beads dengan imobilisasi 1,10fenantrolin. Matriks karagenan dimodifikasi dalam bentuk bead karena bead mempunyai luas permukaan besar yang dapat meningktakan sensitivitas terhdapat suatu interaksi. Selain itu kemampuan dari karagenan dalam membetuk gel.

Karagenan yang terdiri dari 3 jenis yaitu kappa, iota dan lambda mempunyai kemampuan membentuk gel yang berbeda. Semakin sedikit gugus anionik ester sulfat maka viskositas larutan karagenan semakin kecil, tetapi konsistensi gel semakin meningkat. Lambda tidak dapat membentuk gel. Kappa karagenan mempunyai sifat gel yang kaku, kuat dan mudah pecah ditandai dengan tingkat sineresis (kemudahan gel mengkerut) yang tinggi selama penyimpanan. Iota karagenan tidak mudah sineresis, tetapi sifat gel lemah (Ledlein and Sisson, 2011). Kombinasi iota dan kappa karagenan dapat meningkatkan elastisitas gel dan mencegah sineresis. Hal tersebut ditunjukkan pada Gambar 1.

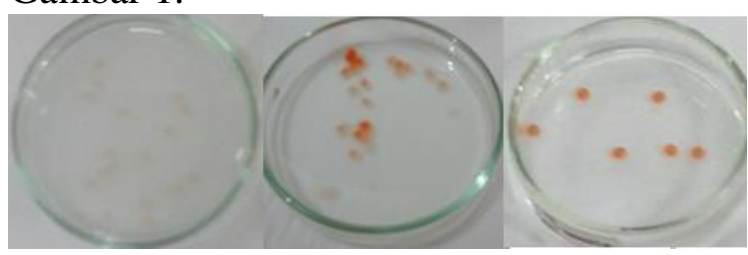

Gambar 1 menunjukkan semakin banyak kemungkinan gugus anionik dalam beads maka intensitas warna pada beads lebih tinggi. Hal tersebut dapat dipengaruhi adanya gaya elektrostatik antara anionik ester sulfat pada karagenan dengan kompleks kationik yang terbentuk dalam beads sehingga kompleks terikat di dalam beads. Beads campuran kappa dan iota menghasilkan sensor warna logam besi tanpa pelindian dan menunjukkan intensitas warna.

\section{Karakterisasi Beads Karagenan}

Spektra inframerah beads campuran kappa dan iota karagenan sebelum digunakan untuk deteksi kolorimetri Fe tidak terdapat pergeseran atau perubahan posisi daerah bilangan gelombang gugus fungsi karaginan. Spektra inframerah pada beads dengan imobilisasi 1,10-fenantrolin setelah digunakan untuk deteksi kolorimetri $\mathrm{Fe}$ menunjukkan terjadi perubahan daerah serapan dari $\mathrm{S}=\mathrm{O}$ pada ester sulfat dari $1258 \mathrm{~cm}^{-1}$ menjadi 1234 $\mathrm{cm}^{-1}$. Hal tersebut dapat disebabkan adanya interaksi elektrostatik antara komplek kationik yang terbentuk antara $\mathrm{Fe}^{2+}$ dan 1,10fenantrolin dengan anionik ester sulfat pada karaginan. Perubahan daerah serapan $\mathrm{S}=\mathrm{O}$ pada ester sulfat juga ditemukan pada interaksi elektrostatik antara anionik ester sulfat pada karaginan yang bermuatan negatif dengan ammonium pada kitosan yang bermuatan positif yaitu dari $1261 \mathrm{~cm}^{-1}$ menjadi $1249 \mathrm{~cm}^{-1}$ [9].

\section{Panjang Gelombang Maksimum}




\section{Konsentrasi Optimum Imobilisasi 1,10- fenantrolin}

diperoleh dari scanning beads yang terlebih dahulu beads dimasukkan ke dalam larutan $\mathrm{Fe}^{2+}$ pada konsentrasi 3, 5 dan10 $\mathrm{mg} \mathrm{L}^{-1}$ sehingga terjadi perubahan warna pada beads. Beads yang telah mengalami perubahan warna yang digunakan untuk optimasi panjang gelombang maksimum. Scanning beads dilakukan pada panjang gelombang visibel yaitu pada daerah 450-550 nm. Kurva penentuan panjang gelombang maksimum ditunjukkan pada Gambar 2.

Gambar 2 menunjukkan beads bewarna jingga kemerahan dari kompleks $\left[\mathrm{Fe}(\text { phen })_{3}\right]^{2+}$ mempunyai panjang gelombang maksimum sebesar $510 \mathrm{~nm}$. Panjang gelombang maksimum yang diperoleh berguna untuk meminimalkan atau menghindari gangguan yang mungkin dapat ditimbulkan dari senyawa atau logam lain. Senyawa kompleks mampu menyerap cahaya pada panjang gelombantertentu yang spesifik. Hasil panjang gelombang yang diperoleh seperti yang terdapat pada beberapa penelitian tentang kompleks $\left[\mathrm{Fe}(\text { phen })_{3}\right]^{2+}$ yaitu sebesar $510 \mathrm{~nm}$ dalam kondisi larutan [14], $515 \mathrm{~nm}$ dalam bentuk membran [7].

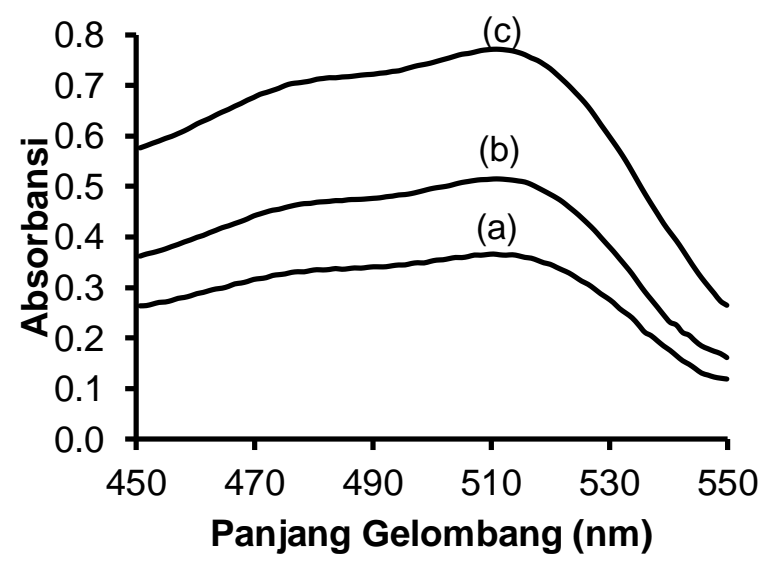

Gambar 2 Kurva penentuan panjang gelombang maksimum pada konsentrasi $\mathrm{Fe}^{2+}$ (a) 3 $\mathrm{mg} \mathrm{L}{ }^{-1}$ (b) $5 \mathrm{mg} \mathrm{L}^{-1}$ (c) $10 \mathrm{mg} \mathrm{L}^{-1}$

Optimasi konsentrasi 1,10-fenantrolin di dalam beads bertujuan untuk memperoleh intensitas warna maksimum dalam beads. Perubahan warna di dalam beads diperoleh dari interaksi antara $\mathrm{Fe}^{2+}$ dengan 1,10-fenantrolin yang menghasilkan kompleks $\left[\mathrm{Fe}(\text { phen })_{3}\right]^{2+}$ berwarna merah jingga. Kandungan 1,10fenantrolin pada variasi fenantorlin 1000, 2000, 3000, 4000 dan $5000 \mathrm{mg} \mathrm{L}^{-1}$.setiap gram beads yang terbentuk masing-masing sebesar $3,82,7,64,11,46,15,27$ dan $19,10 \mathrm{mg} \mathrm{g}^{-1}$. Beads dari masing-masing variasi konsentrasi 1,10-fenantrolin dimasukkan ke dalam larutan $\mathrm{Fe}^{2+}$ dengan konsentrasi 2, 5 dan $10 \mathrm{mg} \mathrm{L}^{-1}$ hingga beads berubah warna. Beads yang telah berubah warna dipisahkan dari larutan dan diukur absorbasinya dengan Spektrofotometer UV-Vis ditunjukkan Gambar 3.

Konsentrasi optimum 1,10-fenantrolin yang diimobilisasi ke dalam beads dapat ditunjukkan pada Gambar 3 melalui nilai absorbansi spektrofotometer UV-Vis. Hasil menunjukkan konsentrasi optimum 1,10fenantrolin yang diimobilisasi di dalam beads adalah 11,46 $\mathrm{mg} \mathrm{g}^{-1}$. Pada 1,10-fenantrolin $15,27 \mathrm{mg} \mathrm{g}^{-1}$ dan $19,10 \mathrm{mg} \mathrm{g}^{-1}$ mempunyai visual warna yang sama dengan 1,10fenantrolin11,46 $\mathrm{mg} \mathrm{g}^{-1}$. Hal tersebut menunjukkan beads mempunyai kapasitas optimum untuk menampung kompleks yang terebntuk. Beads dari campuran kappa dan iota karagenan mengandung gugus fungsional yang memberikan interaksi elektrostatik dengan kompleks kation $\left[\mathrm{Fe}(\text { phen })_{3}\right]^{2+}$. Kapasitas kemampuan menampung interaksi tergantung dari jumlah gugus yang ada dalam beads yaitu anionik sulfat ester pada karagenan. 


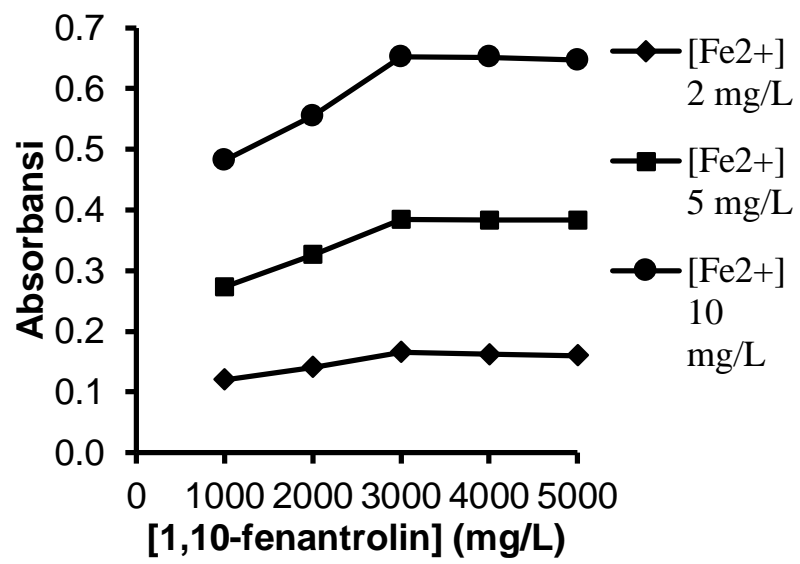

Gambar 3 Kurva absorbansi versus konsentrasi 1,10fenantrolin di dalam beads pada larutan $\mathrm{Fe}^{2+} 2,5$ dan $10 \mathrm{~m} \mathrm{~L}^{-1}$

\section{pH Optimum Larutan Besi}

Kondisi $\mathrm{pH}$ larutan ion $\mathrm{Fe}^{2+}$ mempengaruhi pembentukan kompleks $\mathrm{Fe}^{2+}$ dengan 1,10-fenantrolin. Warna kompleks $\left[\mathrm{Fe}(\text { phen })_{3}\right]^{2+}$ terbentuk stabil pada rentang $\mathrm{pH}$ 2-9 [1]. Pada penelitian ini rentang $\mathrm{pH}$ larutan ion $\mathrm{Fe}^{2+}$ yang digunakan untuk optimasi yaitu pH 2-6 dan pada konsentrasi larutan $\mathrm{Fe}^{2+}$ yang

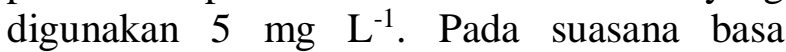
kompetisi $\mathrm{Fe}^{2+}$ dengan $\mathrm{OH}^{-}$menyebabkan kompleks $\left[\mathrm{Fe}(\text { phen })_{3}\right]^{2+}$ yang terbentuk kurang optimum dibandingkan pada suasana asam. Ion $\mathrm{Fe}^{2+}$ dapat bereaksi dengan $\mathrm{OH}^{-}$menghasilkan endapan $\mathrm{Fe}(\mathrm{OH})_{2}$ yang dapat menghalangi terbentuknya kompleks $\left[\mathrm{Fe}(\text { phen })_{3}\right]^{2+}$. Optimasi $\mathrm{pH}$ larutan ion $\mathrm{Fe}^{2+}$ ditunjukkan pada Gambar 4. Hasil optimasi $\mathrm{pH}$ larutan ion $\mathrm{Fe}^{2+}$ diperoleh pada $\mathrm{pH} 2$ karena beads mengalami pelindian pada $\mathrm{pH} 3$ hingga 6 .

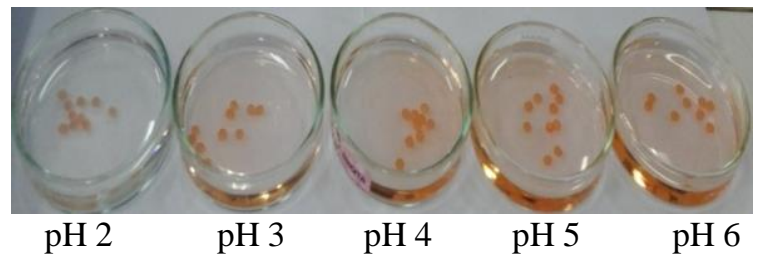

GambarError! No text of specified style in document. 4 Beads di dalam larutan ion $\mathrm{Fe} 2+$ pada variasi $\mathrm{pH} 2,3,4,5$, dan 6

\section{Waktu Kestabilam Sensor}

Kompleks $\mathrm{Fe}^{2+}$ dengan 1,10-fenantrolin memberikan warna merah jingga yang mempunyai stabilitas tinggi. Pengujian waktu optimum pembentukan kompleks di dalam beads dengan menggunakan spektrofotometer dan hasilnya dapat ditunjukkan pada Gambar 5. Waktu pembentukan kompleks diukur hingga 30 menit dan nilai absorbansi terukur setiap 3 menit.

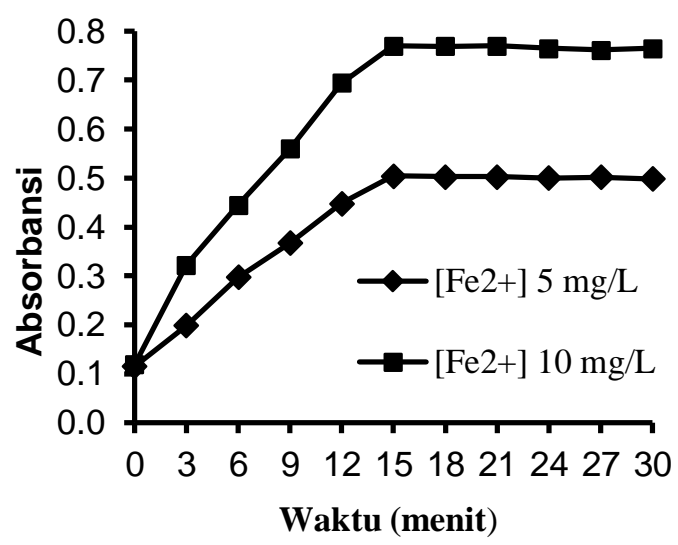

Gambar 5 Waktu Kestabilan Sensor

Gambar 5 menunjukkan waktu dengan absorbansi maksimum yaitu 15 menit dan stabil hingga 30 menit. Hal tersebut menunjukkan intensitas maksimum warna pada beads yaitu 15 menit. Data nilai absorbansi ditunjukkan pada Lampiran 8 . Kestabilan warna kompleks di dalam beads menunjukkan adanya interaksi elektrostatik antara gugus anionik di dalam beads dengan komplek kationik . Hasil yang diperoleh sama dengan waktuk kompleks $[\mathrm{Fe}($ phen) 3$] 2+$ di dalam bentuk membrane dari polimer sintetik yaitu 15 menit [7].

\section{KESIMPULAN}

Karagenan dapat dignakan sebagai matriks dalam sensor warna logam besi di dalam air. Matriks karagenan dari jenis kappa dan iota yang dapat digunakan untuk 
menghasilkan sensor warna tanpa pelindian. Hal tersebut disebabkan karagenan mempunyai gugus anionik yang dapat menahan kompleks kationik di dalamnya. Matriks dibuat dalam bentuk beads dengan memanfaatkan sifat hidrogel dari karagenan kappa dan iota, sedangkan jenis lambda tidak.

Bentuk beads mempunyai luas permukaan besar yang dapat meningkatkan sensitivitas terhadap suatu interaksi serta mudah dan murah dalam pembentukannya. Campuran karagenan kappa dan iota dapat dijadikan matriks dalam sensor warna logam besi sebagai pengimobilisasi 1,10-fenantrolin. Hasil optimasi kondisi pada beads memberikan sensor warna yang optimum pada panjang gelombang $510 \mathrm{~nm}$, konsentrasi 1,10fenantrolin yang diimobilisasi $3000 \mathrm{mg} \mathrm{L}^{-1}$ volume total larutan pembuat beads, $\mathrm{pH}$ larutan besi adalah 2 dan waktu kompleksasi 15 menit.

\section{DAFTAR PUSTAKA}

[1] Adhikamsetty, R. K., Gollapalli, N. R., \& Jonnalagadda, S. B. (2008).

Complexation kinetics of $\mathrm{Fe} 2+$ with 1,10-phenanthroline forming ferroin in acidic solutions. In International Journal of Chemical Kinetics (Vol. 40, Issue 8, pp. 515-523). https://doi.org/10.1002/kin.20336

[2] Azmi, N. A., Ahmad, S. H., \& Low, S. C. (2018). Detection of mercury ions in water using a membrane-based colorimetric sensor. RSC Advances, 8(1), 251-261.

https://doi.org/10.1039/c7ra11450h

[3] Chochorek, A., Bobrowski, A., Kiralyova, Z., \& Mocak, J. (2010). ICP-OES

Determination of Select Metals in Surface Water - a Metrological Study. 19(1), 59-64.

[4] Dragan, E. S., Felicia, D., Loghin, A., \& Cocarta, A. I. (2014). E ffi cient Sorption of $\mathrm{Cu} 2+$ by Composite Chelating Sorbents Based on Potato Starch- graf $t$ Polyamidoxime Embedded in Chitosan Beads.

[5] Huang, X., Hao, Y., Wu, H., Guo, Q., Guo, L., Wang, J., Zhong, L., Lin, T., Fu, F., \& Chen, G. (2014). Sensors and Actuators B : Chemical Magnetic beads based colorimetric detection of mercuric ion. Sensors \& Actuators: B. Chemical, 191, 600-604.

https://doi.org/10.1016/j.snb.2013.10.025

[6] Kologo, S., Eyraud, M., Bonou, L.,

Vacandio, F., \& Massiani, Y. (2007).

Voltametry and EQCM study of copper oxidation in acidic solution in presence of chloride ions. In Electrochimica Acta (Vol. 52, Issue 9, pp. 3105-3113). https://doi.org/10.1016/j.electacta.2006.0 9.052

[7] Kumar, S. A., Thakur, N., Parab, H. J., Pandey, S. P., Shinde, R. N., Pandey, A. K., Kumar, S. D., \& Reddy, A. V. R. (2014). Analytica Chimica Acta A visual strip sensor for determination of iron. Analytica Chimica Acta, 851, 87-94. https://doi.org/10.1016/j.aca.2014.08.047

[8] Lagerström, M. E., Field, M. P., Séguret, M., Fischer, L., Hann, S., \& Sherrell, R. M. (2013). Automated on-line fl owinjection ICP-MS determination of trace metals ( $\mathrm{Mn}, \mathrm{Fe}, \mathrm{Co}, \mathrm{Ni}, \mathrm{Cu}$ and $\mathrm{Zn}$ ) in open ocean seawater: Application to the GEOTRACES program. Marine Chemistry, 155, 71-80. https://doi.org/10.1016/j.marchem.2013. 06.001

[9] Li, C., Hein, S., \& Wang, K. (2013). Chitosan-Carrageenan Polyelectrolyte Complex for the Delivery of Protein Drugs. ISRN Biomaterials, 2013, 1-6. https://doi.org/10.5402/2013/629807

[10] Necas, J., \& Bartosikova, L. (2013). Carrageenan : a review. 2013(4), 187205. 
[11] Ondigo, D. A., Tshentu, Z. R., \& Torto, N. (2013). Analytica Chimica Acta Electrospun nanofiber based colorimetric probe for rapid detection of $\mathrm{Fe} 2+$ in water. Analytica Chimica Acta, 804, 228-234. https://doi.org/10.1016/j.aca.2013.09.051

[12] Popa, E. G., Gomes, M. E., \& Reis, R. L. (2011). Cell Delivery Systems Using Alginate - Carrageenan Hydrogel Beads and Fibers for Regenerative Medicine Applications.

[13] Rajendraprasad, N., \& Basavaiah, K. (2010). Highly Sensitive Spectrophotometric Determination of Olanzapine Using Cerium ( IV) and Iron (II) Complexes of 1, 10 Phenanthroline and 2, 2 'Bipyridyl 1. 65(5), 482-488. https://doi.org/10.1134/S1061934810050 084

[14] Sari, N., \& Sugiarso, D. (2015). Studi Gangguan $\mathrm{Mg}$ (II) dalam Analisa Besi(II) dengan Pengompleks O-1,10-fenantrolin Menggunakan Spektrofotometri UV-Vis. In Jurnal Sains dan Seni ITS (Vol. 4, Issue 1, pp. 8-12).

[15] Sharif, T., Niaz, A., Najeeb, M., Zaman, M. I., Ihsan, M., \& Sirajuddin. (2015). Isonicotinic acid hydrazide-based silver nanoparticles as simple colorimetric sensor for the detection of $\mathrm{Cr} 3+$. Sensors and Actuators B: Chemical, 216, 402408. https://doi.org/10.1016/j.snb.2015.04.043

[16] Tautkus, S., Steponeniene, L., \& Kazlauskas, R. (2006). Determination of iron in natural and mineral waters by flame atomic absorption spectrometry. 69(5), 393-402.

[17] Terra, I. A. A., Mercante, L. A., Andre, R. S., \& Correa, D. S. (2017).

Fluorescent and colorimetric electrospun nanofibers for heavy-metal sensing. In Biosensors (Vol. 7, Issue 4). https://doi.org/10.3390/bios7040061
[18] Woźnica, E., Wójcik, M. M., Wojciechowski, M., Mieczkowski, J., Bulska, E., Maksymiuk, K., \& Michalska, A. (2012). Dithizone modified gold nanoparticles films for potentiometric sensing. In Analytical Chemistry (Vol. 84, Issue 10, pp. 44374442). https://doi.org/10.1021/ac300155f

[19] Zhang, C., Li, H., Yu, Q., Jia, L., \& Wan, L. Y. (2019). Poly(aspartic acid) Electrospun Nanofiber Hydrogel Membrane-Based Reusable Colorimetric Sensor for $\mathrm{Cu}(\mathrm{II})$ and $\mathrm{Fe}(\mathrm{III})$ Detection. ACS Omega. https://doi.org/10.1021/acsomega.9b0210 9 